\title{
Testbed Komunikasi Terintegrasi untuk Angkutan Massal Cepat Surabaya
}

\author{
Tiffany Maliati Khumairoh Afandi, Dr. Ir. Achmad Affandi, DEA, dan Ir. Djoko Suprajitno R, MT \\ Jurusan Teknik Elektro, Fakultas Teknologi Industri, Institut Teknologi Sepuluh Nopember (ITS) \\ Kampus ITS, Keputih-Sukolilo, Surabaya 60111 Indonesia \\ e-mail: affandi@ee.its.ac.id, djokosr@ee.its.ac.id, tiffany.maliati12@mhs.ee.its.ac.id
}

\begin{abstract}
Abstrak-Pemanfaatan teknologi informasi sebagai sarana pengelolaan Kota Surabaya dapat meningkatkan keefektifan pelayanan publik. Salah satu caranya adalah dengan penggunaan On-Board Unit (OBU) pada Angkutan Massal Cepat yang akan diterapkan di Kota Surabaya. OBU adalah terminal elektronik yang dapat memberikan informasi mengenai identitas dan posisi AMC, dan menghubungkan komunikasi antara $\mathrm{CC}$ ROOM dengan pengemudi. Tugas akhir ini bertujuan untuk merancang sebuah sistem yang digunakan pada testbed komunikasi yang terintegrasi antara OBU (client) dengan CCROOM (server).

Perancangan dan implementasi dilakukan dalam 2 tahap, yaitu membuat arsitektur jaringan dan aplikasi sistem clientserver yang digunakan untuk sistem komunikasi terintegrasi AMC. Aplikasi pengiriman data dari client ke server dibuat dengan menggunakan Borland Delphi 7. Jaringan yang digunakan yaitu jaringan seluler dan jaringan backbone.

Pengujian sistem komunikasi terintegrasi AMC dilakukan dengan 2 macam pengujian, yaitu pengujian sistem client-server dan pengujian jaringan sistem yang terdiri dari packet loss dan throughput. Dari hasil pengujian packet loss dan throughput didapatkan rekomendasi ukuran data yang dapat diterapkan pada sistem komunikasi terintegrasi angkutan massal cepat Surabaya, yaitu sebesar 450 byte.
\end{abstract}

Kata kunci-Intelligent Transportation System, Packet Loss, Testbed, Throughput

\section{PENDAHULUAN}

$\mathrm{K}$ OTA Surabaya mengalami peningkatan jumlah kendaraan pribadi yang besar dari tahun ke tahun sehingga dapat menyebabkan kepadatan lalu lintas di ruas jalan raya Surabaya. Salah satu penyebabnya adalah kurangnya moda transportasi publik yang memadai. Badan Perencanaan Pembangunan Nasional (Bappenas) telah memperkirakan Angkutan Massal Cepat (AMC) Kota Surabaya beroperasi pada tahun 2017. Proyek AMC Kota Surabaya telah masuk dalam Rancangan Program Jangka Menengah Nasional (RPJMN) Bappenas tahun 2015-2019. Hal ini menunjukkan bahwa pemerintah Kota Surabaya telah berkomitmen untuk membangun sebuah Angkutan Massal Cepat (AMC) untuk mengurangi kemacetan lalu lintas di Kota Surabaya.

Angkutan Massal Cepat (AMC) memiliki sistem komunikasi terintegrasi dengan wujud pemasangan On-Board Unit (OBU) pada setiap armada dan sistem Passenger Information Board (PIB) pada halte. Data dari OBU akan melewati jaringan seluler sedangkan data dari PIB akan melewati jaringan backbone. Kemudian data tersebut akan diterima oleh Control Center Room (CC-ROOM). Untuk menguji pengiriman data di perlukan suatu testbed terhadap prototype dari sistem tersebut.

Oleh karena itu perlu dibuat sebuah aplikasi yang mampu mesimulasikan testbed pada sejumlah titik OBU dan PIB. Dalam tugas akhir ini, aplikasi dibuat menggunakan software Borland Delphi 7. Aplikasi ini bertindak sebagai client yang memasukkan data untuk dikirim ke server. Server akan memberi balasan ke client dan menyimpan data dalam bentuk database server. Data yang disimpan oleh server antara lain identitas, lokasi, waktu kirim, ip pengirim, waktu terima, dan nomer paket. Data tersebut digunakan untuk mengetahui packet loss dan throughput.

\section{DASAR TEORI}

\section{A. Angkutan Massal Cepat Surabaya}

Angkutan massal cepat Surabaya biasa disebut sebagai Suratram dan Boyorail. Kedua jenis moda transportasi ini menghubungkan Surabaya bagian timur-barat dan utaraselatan. Surotram menghubungkan Surabaya bagian utara sampai Surabaya bagian selatan dengan total jarak $\pm 16,7 \mathrm{Km}$ dan melewati 26 titik halte. Daerah yang dilewati oleh Surotram yaitu Sonokembang, Bambu Runcing, Gub. Suryo, Tunjungan, Genteng, Siola, Baliwerti, Tugu Pahlawan, Veteran, Jembatan Merah, Rajawali, Indrapura, Kemayoran, Pasar Turi, Bubutan, Pasar Blauran, kedungdoro, Embong Malang, Tegalsari, Kombepol M Duryat, Panglima Sudirman, Pandegiling, Bintoro, Taman Bungkul, Bonbin, dan Joyoboyo. Boyorail menghubungkan Surabaya bagian timur sampai bagian barat dengan total jarak $\pm 23 \mathrm{Km}$ dan melewati 24 titik halte. Daerah yang dilewati oleh Boyorail yaitu Kejawan, Mulyosari ITS, Gor Kertajaya, Dharmahusada Indah Timur, RS DR Sutomo, Stasiun Gubeng, Jl. Raya Gubeng, Irian Barat, Bung Tomo, Ngagel, Wonokromo, Joyoboyo, Adityawarman, Pakis, Dukuh Kupang, Bundaran Satelit, HR Muhammad, Simpan Darmo Permai, Lontar, Unesa, dan Lidah Kulon.

\section{B. Sistem Client-Server}

Client-server merupakan teknologi pendistribusian kerja aplikasi antara dua komputer atau lebih yang dihubungkan oleh jaringan komunikasi, dimana yang satu akan bertindak sebagai server atau pemberi layanan dan yang lainnya sebagai client atau peminta layanan. Baik client maupun server memiliki pemroses atau CPU sendiri sedangkan jaringan yang digunakan bisa berupa jaringan lokal (LAN) ataupun jaringan yang lebih luas (WAN) [1]. 


\section{Borland Delphi 7}

Delphi adalah sebuah bahasa pemrograman yang bersifat OOP (Object Oriented Programming), artinya sebuah program yang mempunyai objek-objek tertentu dalam pemrogramannya. OOP ini memiliki beberapa unsur yaitu: Encapsulation (pemodelan), Inheritance (penurunan), Polymorphism (polimorfisme). Selain itu, Delphi adalah sebuah program yang bersifat visual, artinya mempunyai tampilan grafik-grafik yang mudah dimengerti oleh pemula sekalipun (Graphical User Interface) [3].

\section{Packet Loss}

Packet loss merupakan banyaknya paket yang gagal mencapai tempat tujuan. Ketika packet loss besar maka dapat diketahui bahwa jaringan sedang sibuk atau terjadi overload Dinyatakan dalam persen (\%) [4].

$$
\text { Packet loss rate }=\left(\frac{\text { total packet loss }}{\text { total packet sent }}\right) * 100 \%
$$

\section{E. Throughput}

Throughput diartikan sebagai laju data aktual per satuan waktu (bits per second). Biasanya throughput selalu dikaitkan dengan bandwidth. Karena throughput memang bisa disebut sebagai bandwidth dalam kondisi yang sebenarnya. Bandwidth lebih bersifat tetap sementara throughput sifatnya dinamis tergantung trafik yang sedang terjadi.

Cara untuk menghitung throughput sebagai berikut:

$$
\text { throughput }=\frac{\text { jumlah data yang diterima }}{\text { waktu pengiriman }}
$$

\section{F. PHP MyAdmin}

Salah satu perangkat lunak yang digunakan untuk mengelola database dalam MySQL adalah PHPMyAdmin. Dengan PHPMyAdmin kita dapat dengan mudah membuat tabel, mengisi data, dan banyak lagi hal lainnya yang tanpa harus hafal perintahnya, namun cukup dengan mengisi tabeltabel yang telah tersedia [2].

\section{METODOLOGI}

Pada tugas akhir ini membahas perancangan testbed sistem client-server komunikasi terintegrasi Angkutan Massal Cepat Surabaya, dimana pembagiannya meliputi perancangan arsitektur jaringan, perancangan aplikasi, dan perancahngan database. Dalam pembuatan sistem ini pertama kali dilakukan adalah mengetahui proses komunikasi terintegrasi AMC. Berikut ini adalah diagram alur sistem yang ditunjukkan dalam Gambar 1:

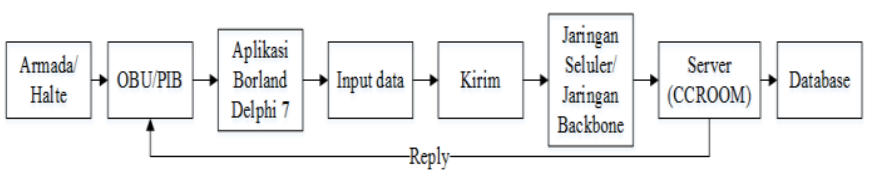

Gambar 1 Diagram blok sistem jaringan komunikasi AMC

On-Board Unit (OBU) berada pada tiap armada sedangkan Passenger Information Board (PIB) berada pada halte. Pada OBU dan PIB akan di install aplikasi yang telah dibuat menggunakan software Borland Delphi 7. Untuk mengirimkan data ke server (CCROOM), client harus memasukkan beberapa data sesuai dengan kolom yang terdapat pada aplikasi. Kemudian data dikirim ke server. Jika pengiriman data menggunakan $\mathrm{OBU}$, maka data dikirim melalui jaringan seluler. Jika pengiriman data menggunakan PIB, maka data dikirim melalui jaringan backbone. Setelah data diterima oleh server, server akan memberi balasan ke client. Selanjutnya data dimasukkan ke database untuk diolah.

\section{A. Perancangan Aplikasi pada Borland Delphi 7}

Aplikasi yang dibuat telah dirancang berfungsi sebagai client. Berikut flowchart aplikasi client Borland Delphi 7:

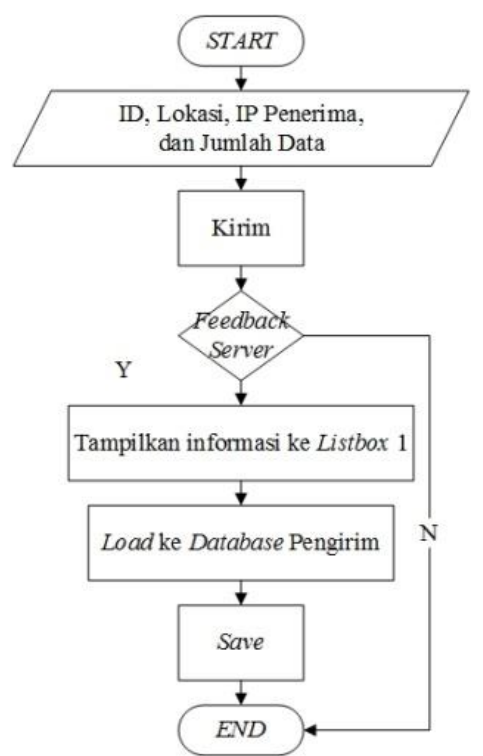

Gambar 2 Flowchart aplikasi Borland Delphi

Dapat dilihat pada Gambar 2 mengenai alur aplikasi untuk uji coba. Client koneksi ke jaringan internet. Client memasukkan atau meng-inputkan data ID, Lokasi, IP penerima, dan jumlah data pada aplikasi Borland Delphi 7 yang telah dibuat. Kemudian data-data tersebut dikirim ke server. Server telah terhubung dengan database PHPMyAdmin. Client akan mendapat feedback (umpan balik) setelah data terkirim ke server. Feedback tersebut berupa informasi yang muncul pada ListBox 1. Informasi yang didapat yaitu balasan dari server berupa ID, lokasi, tanggal pengiriman, dan waktu pengiriman per paket data. Balasan dari server dapat di konversi ke database dengan format CSV (Comma Separated Value). Caranya adalah dengan menekan "Database Pengirim", maka balasan dari server tersebut akan di muat terlebih dahulu dalam bentuk tabel yang ditampilkan pada StringGrid 1.

Adapun penjelasan proses load data ke StringGrid 1 Pertama, data dari ListBox 1 diolah untuk ditampilkan dalam bentuk tabel pada StringGrid 1. Jumlah baris tabel StringGrid 1 sebanyak jumlah item ListBox 1 (data masuk). Pemisahan masukan data per kolom menggunakan "," sebagai acuan. Tabel pada aplikasi ini terdapat 5 kolom, yaitu Identity, latitude, longitude, date, dan TimeSent. Jika data yang masuk sudah sesuai dengan baris dan kolom yang diinginkan, proses berakhir. 


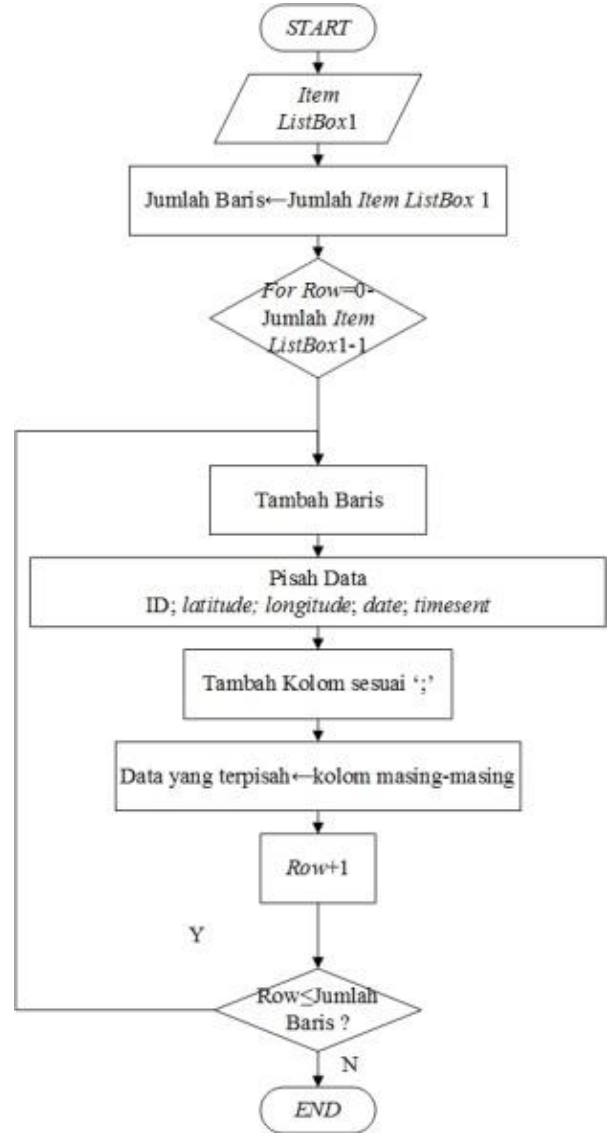

Gambar 3 Flowchart proses load ke dalam bentuk tabel

Kemudian tabel dapat disimpan ke memori komputer dengan menekan "Save DB Pengirim". Alur pemrograman untuk menyimpan data ke format CSV dijelaskan pada Gambar 4:

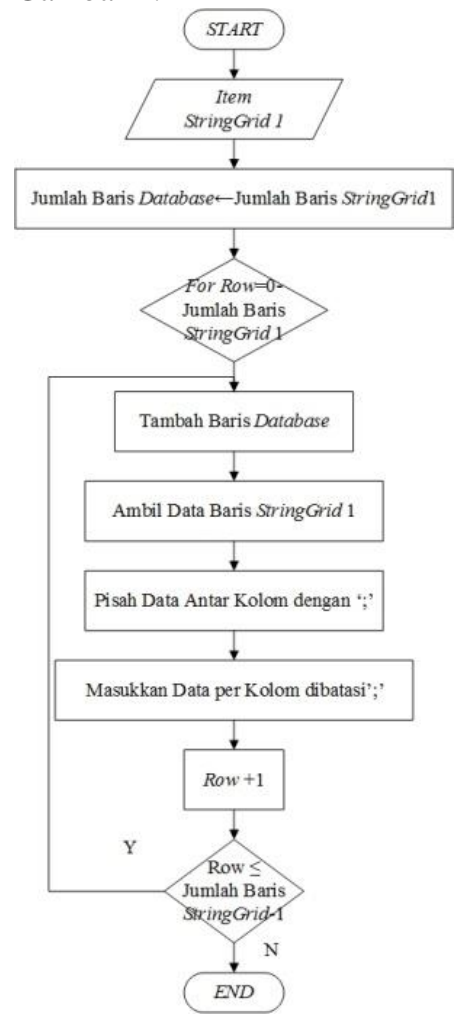

Gambar 4 Flowchart proses save dalam format CSV
Data input merupakan item dari StringGrid1. Jumlah baris pada StringGrid 1 dijadikan acuan jumlah baris file CSV. Proses selanjutnya data pada setiap baris StringGrid 1 akan dikonversi menurut aturan CSV. Pemisah data antar kolom (delimiter) menggunakan “;”. Jumlah kolom pada tabel ada lima. Sehingga pada file CSV terdapat empat ";" untuk memisahkan data antar kolom. Pemisahan data pada file CSV menjadi "Identity, latitude, longitude, date, TimeSent". Jika sudah sesuai data dari StringGrid1 maka proses berakhir.

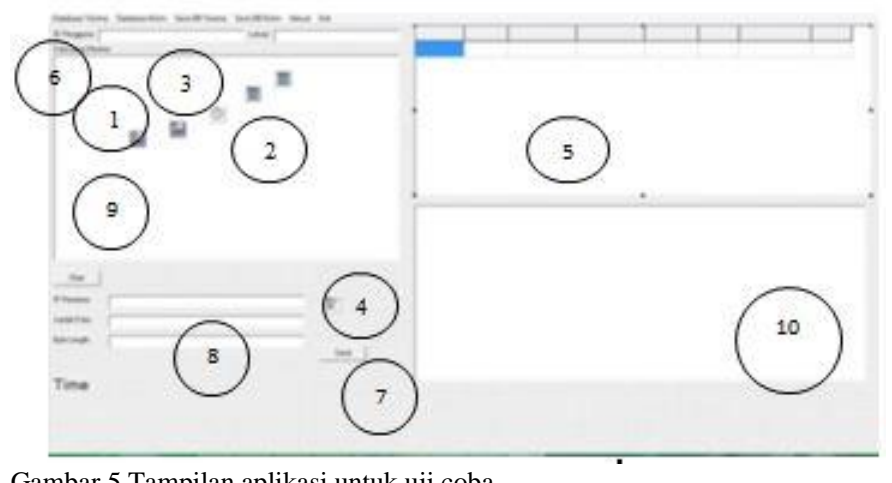

Gambar 5 Tampilan aplikasi untuk uji coba

Setelah pembuatan alur aplikasi, dibuatlah aplikasi pengiriman dan penerimaan data pada Borland Delphi 7. Tampilan (interface) aplikasi yang dibuat pada Borland Delphi 7 dapat dilihat pada Gambar 5. Dibutuhkan beberapa komponen form, yaitu:

1. UDP, berfungsi untuk mengirim dan menerima data.

2. Save Dialog, berfungsi untuk menampilkan jendela save database.

3. Timer, berfungsi untuk membangkitkan waktu pada aplikasi.

4. Menu files, berfungsi untuk membuat desain menu pada aplikasi.

5. StringGrid, berfungsi untuk membuat tabel pada aplikasi

6. ListBox,berfungsi untuk menampilkam informasi yang dibutuhkan.

7. Button, berfungsi sebagai komponen tambahan yang membutuhkan tombol.

8. Edit text, berfungsi sebagai komponen tambahan untuk memasukkan atau mengeluarkan sebuah informasi.

9. Label, berfungsi sebagai pemberi keterangan yang dibutuhkan.

10. Memo, berfungsi untuk menampilkan informasi.

\section{B. Perancangan Database PHPMyAdmin}

Server yang digunakan untuk menerima data dalam tugas akhir ini adalah server its2.lawanghosting.pw dengan memanfaatkan database PHPMyAdmin pada server. Data yang masuk ke server akan disimpan dalam database its2016a. Database dibuat sesuai dengan format perancangan sistem komunikasi terintegrasi AMC. Tabel yang terdapat pada database yaitu tabel udp_rxlog. Berikut Gambar 6 yang merupakan tampilan struktur dari tabel udp_rxlog: 


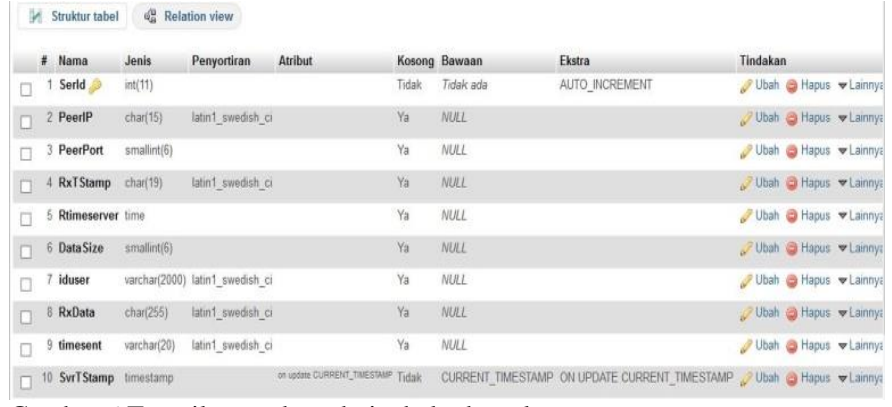

Gambar 6 Tampilan struktur dari tabel udp_rxlog

Gambar 6 adalah tampilan tabel udp_rxlog. Dalam tabel tersebut terdapat beberapa field antara lain:

1. SerID, berisi id ID urutan data yang masuk ke server

2. PeerIP, berisi IP client yang mengirimkan data.

3. PeerPort, berisi port berapa yang dilewati

4. RxTStamp, berisi waktu data diterima database server.

5. Rtimeserver, berisi waktu data diterima oleh server.

6. Datasize, berisi ukuran byte data yang diterima

7. RxData, berisi data yang diterima. Data-data yang diterima adalah ID client, longitude, dan latitude

8. Timesent, berisi waktu pengiriman oleh client

9. SvrTStamp, berisi waktu data masuk ke database server

\section{Skenario Pengujian}

Berikut ini Gambar 7 mengenai skenario jaringan:

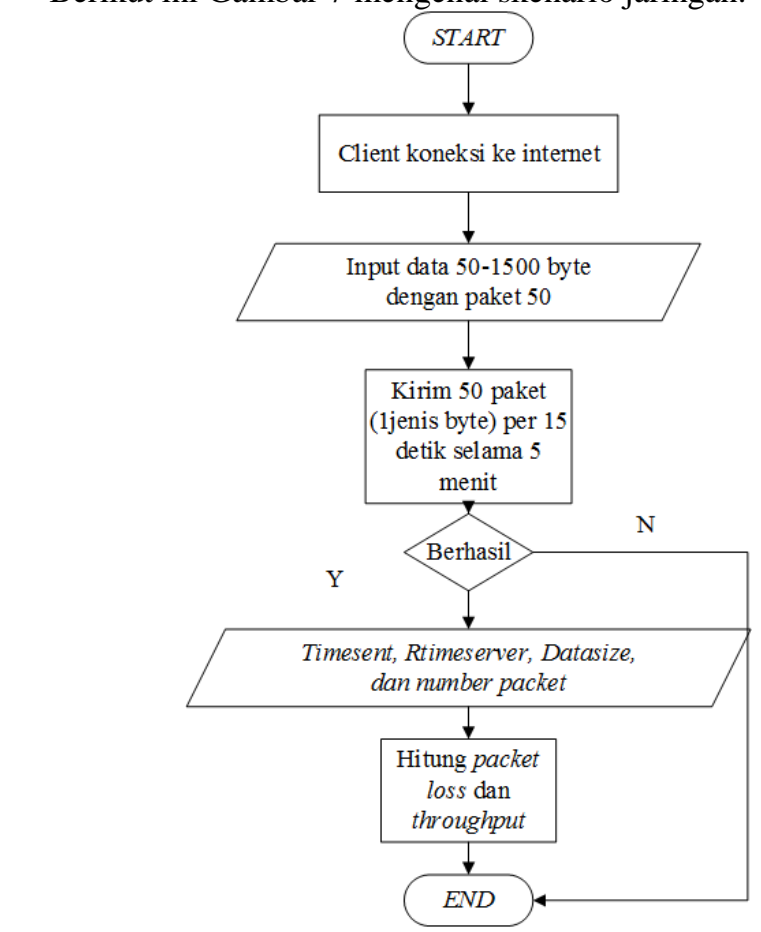

Gambar 7 Skenario pengujian jaringan

Pertama kali yang dilakukan adalah membuka aplikasi testbed komunikasi terintegrasi yang telah dibuat dengan menggunakan aplikasi Borland Delphi 7 pada tiap laptop yang akan digunakan. Laptop yang digunakan berjumlah dua buah. Laptop-laptop tersebut sebagai client yang akan mengirim data ke server its2.lawanghosting.pw yang memiliki IP Public.

Pada pengujian ini, akan dilihat QoS jaringan yang telah dirancang. QoS jaringan yang ditinjau adalah packet loss dan throughput. Langkah-langkah pengujian yang dilakukan yaitu aplikasi telah terkoneksi dengan jaringan Wi-Fi atau jaringan salah satu operator seluler. Kemudian mengatur besar byte data sekitar 50-1500 byte dan paket yang dikirim sebesar 50 paket yang di-inputkan oleh client pada aplikasi testbed komunkasi terintegrasi AMC. 50 paket ini adalah mewakili 50 OBU dan PIB. Pengaturan byte data tersebut bertujuan untuk mendapatkan rekomendasi berapa ukuran data terbaik yang dapat diterima oleh server, data tersebut dikirim melalui jaringan backbone dan jaringan seluler. Range byte 50-1500 byte tersebut diambil dari standar MTU (Maximum Transmission Unit), karena jika ukuran data yang dikirim lebih besar dibandingkan nilai MTU maka paket yang dikirim lebih besar dibandingkan nilai MTU, paket data yang dikirimkan akan terpecah menjadi beberapa fragmen yang akhirnya tidak jadi terkirim dengan benar. Selanjutnya, data dikirim ke server. Pengiriman data ke server per 50 paket satu jenis byte dengan jeda 15 detik sekali kirim dengan rentang waktu 5 menit. Jika berhasil maka didapatkan output timesent, Rtimeserver, datasize, dan number packet yang disimpan dalam database. Timesent, Rtimeserver, datasize, dan number packet digunakan untuk menghitung QoS, yaitu packet loss dan throughput. Apabila data tidak berhasil terkirim ke server maka proses diakhiri.

\section{Konfigurasi Pengukuran Jaringan Wi-Fi}

Arsitektur jaringan pengiriman data ini dibuat dengan menggunakan sistem client-server. Arsitektur dalam Gambar 8 merupakan arsitektur yang digunakan untuk melakukan testbed komunikasi sistem terintegrasi AMC melalui jaringan Wi-Fi.

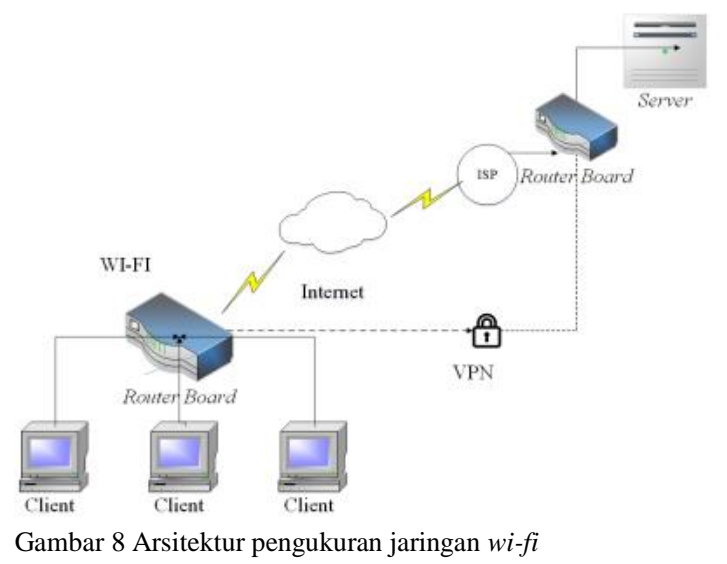

Dalam gambar tersebut terdapat beberapa client sebagai PIB pada halte yang terhubung dengan access point yang dianalogikan sebagai jaringan backbone. Kemudian data dikirim ke server yang memiliki IP Public. Testbed ini dilakukan dalam jaringan Virtual Private Network (VPN).

\section{E. Konfigurasi Pengukuran Jaringan Seluler}

Arsitektur jaringan pengiriman data ini dibuat dengan menggunakan sistem client-server. Arsitektur dalam Gambar 9 merupakan arsitektur yang digunakan untuk melakukan testbed komunikasi sistem terintegrasi AMC melalui jaringan seluler. 
Dalam Gambar 9 beberapa client sebagai OBU pada armada yang terhubung dengan jaringan operator seluler. Kemudian data dikirim ke server yang memiliki IP Public. Testbed ini dilakukan dalam jaringan Virtual Private Network (VPN).

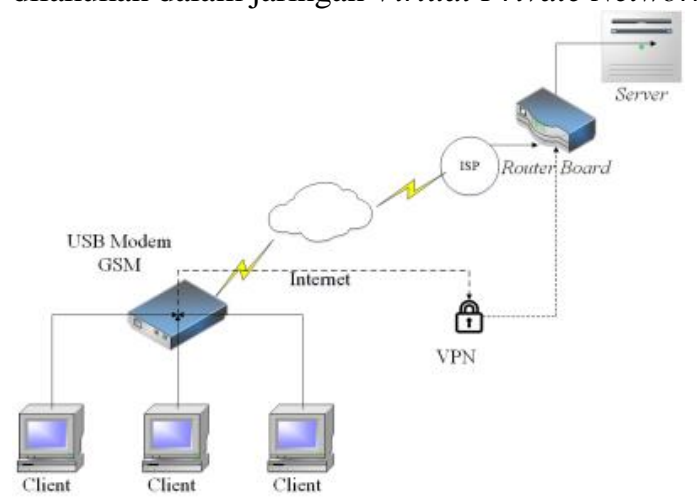

Gambar 9 Arsitektur pengukuran jaringan seluler

\section{IMPLEMENTASI DAN HASIL PENGUJIAN}

\section{A. Pengujian Packet Loss}

Pengujian packet loss digunakan untuk mengetahui paket data yang hilang sewaktu dilakukan pengiriman data dari client ke server. Pengujian ini dilakukan dengan mengirimkan data 50 paket secara terus-menerus selama 5 menit dengan jeda 15 detik per paket. Ukuran data yang dikirim ke server sebesar 50-1500 byte. Pengujian ini dilakukan dengan menggunakan dua laptop yang akan mengirim data secara bersamaan ke server. Satu laptop terkoneksi dengan jaringan $W i-F i$ dan satu laptop terkoneksi dengan jaringan seluler.

Pengujian ini menghasilkan perbandingan antara ukuran data (byte) yang dikirim dengan packet loss ketika pengiriman data menggunakan jaringan Wi-Fi dan jaringan seluler. Berikut hasil dari uji coba:

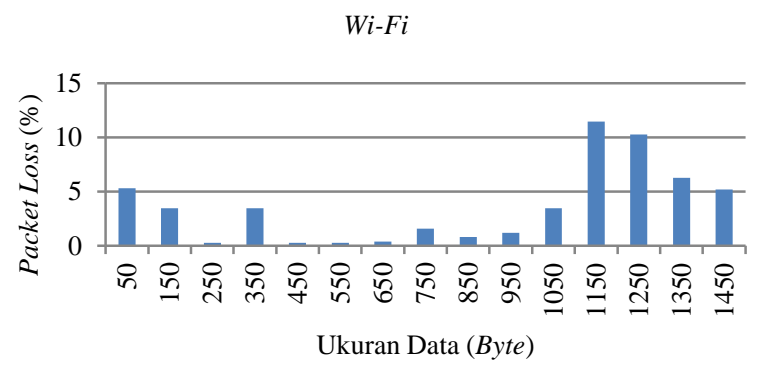

Gambar 10 Grafik packet loss pada Wi-Fi

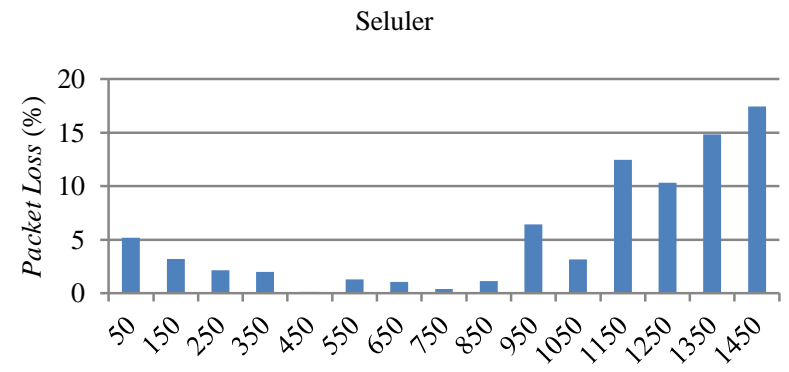

Ukuran Data (Byte)

Gambar 11 Grafik packet loss pada seluler
Pengujian ini menghasilkan nilai packet loss terbesar dan terkecil pada pengiriman data melalui jaringan $W i-F i$ dan jaringan seluler. Pada jaringan Wi-Fi, packet loss terbesar dengan nilai sebesar $11.47 \%$ terletak pada ukuran data 1150 byte. Packet loss terkecil dengan nilai sebesar $0.267 \%$ pada ukuran data 250, 450, dan 550 byte. Pada jaringan seluler, packet loss terbesar dengan nilai sebesar $17.45 \%$ terletak pada ukuran data 1450 byte. Sedangkan untuk nilai packet loss terkecil ketika pengiriman data melalui jaringan seluler sebesar $0.13 \%$ terletak pada ukuran data 450 byte.

Berdasarkan grafik hasil pengujian, dapat dianalisis bahwa timbulnya packet loss disebabkan oleh kepadatan trafik yang menimbulkan antrian sehingga beberapa paket data tidak diterima oleh server. Packet loss seluler lebih besar daripada packet loss Wi-Fi karena kapasitas bandwidth seluler lebih kecil daripada kapasitas bandwidth Wi-Fi.

\section{B. Pengujian Throughput}

Perhitungan parameter ini akan digunakan untuk mendapatkan berapa byte atau jumlah panjang paket data yang optimal untuk dikirimkan pada server. Pengujian ini dilakukan dengan cara yang sama seperti pengujian packet loss, yaitu dengan mengirimkan data 50 paket secara terus menerus selama 5 menit dengan jeda 15 detik per 50 paket. Ukuran data yang dikirim ke server sebesar 50-1500 byte. Pengujian ini dilakukan dengan menggunakan dua laptop yang akan mengirim data secara bersamaan ke server. Satu laptop terkoneksi dengan jaringan Wi-Fi dan satu laptop terkoneksi dengan jaringan seluler.

Pengujian ini menghasilkan perbandingan antara ukuran data (byte) yang dikirim dengan throughput ketika pengiriman data menggunakan jaringan $\mathrm{Wi}-\mathrm{Fi}$ dan jaringan seluler. Berikut hasil dari uji coba:

Wi-Fi

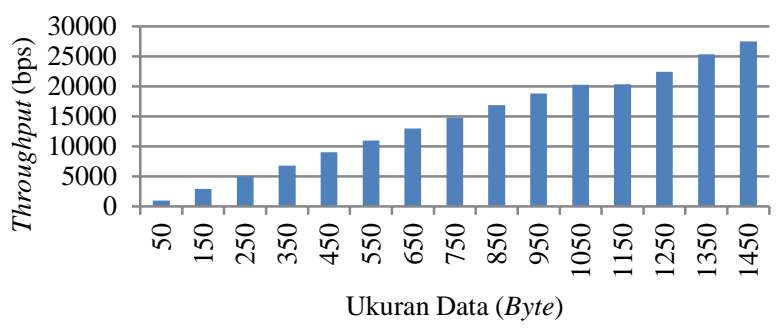

Gambar 12 Throughput pada Wi-Fi

Seluler

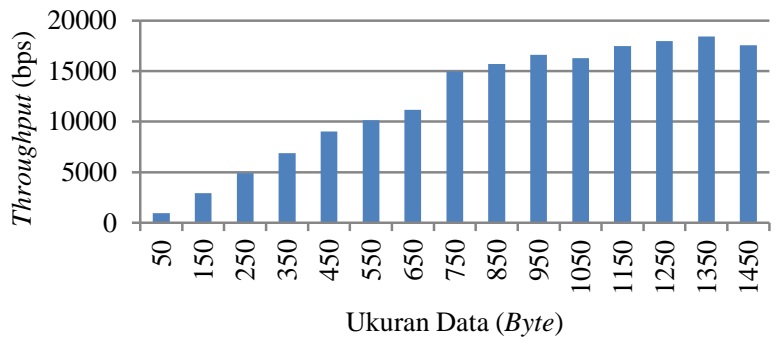

Gambar 13 Throughput pada seluler 
Pengujian ini menghasilkan nilai throughput ketika pengiriman data melalui jaringan $\mathrm{Wi}-\mathrm{Fi}$ dan jaringan seluler. Pada jaringan Wi-Fi didapatkan hasil throughput paling besar terletak pada ukuran data yang paling besar dan yang terkecil terletak pada ukuran data yang paling kecil. Ukuran data terbesar yaitu 1450 byte dengan nilai throughput sebesar 27507.44 bps dan ukuran data terkecil yaitu 50 byte dengan nilai throughput sebesar 962.0533bps. Pada jaringan seluler didapatkan hasil throughput paling besar terletak pada ukuran data sebesar 1350 byte dengan nilai throughput sebesar 18406.77bps. Sedangkan throughput terkecil ketika pengiriman data melalui jaringan seluler terletak pada ukuran data paling kecil. Ukuran data paling kecil yaitu 50 byte dengan nilai throughput sebesar $963.52 \mathrm{bps}$.

Dengan hasil pengujian tersebut, dapat dianalisis jika ukuran data semakin besar, maka nilai throughput yang dihasilkan semakin besar. Nilai throughput didapatkan dari pembagian antara jumlah ukuran data yang diterima dengan waktu pengiriman ke server. Namun pada jaringan seluler nilai throughput terbesar tidak terletak pada ukuran data tertinggi, hal ini terjadi karena pada 1450 byte banyak paket yang hilang.

\section{Rekomendasi Ukuran Data}

Berdasarkan hasil pengujian packet loss dan throughput, didapatkan rekomendasi ukuran data yang bisa digunakan untuk sistem komunikasi terintegrasi angkutan massal cepat Surabaya. Ukuran data yang sebaiknya digunakan adalah sebesar 450 byte. Pemilihan ukuran data sebesar 450 byte sebagai rekomendasi untuk sistem komunikasi terintegrasi angkutan massal cepat Surabaya dikarenakan ukuran data 450 byte memiliki nilai packet loss yang kecil, nilai throughput yang cukup bagus dan panjang data yang mencukupi (tidak terlalu pendek dan tidak terlalu panjang). Ukuran data 450 byte memiliki kualitas packet loss perfect berdasarkan standar versi TIPHON dan baik berdasarkan standar ITU-T G.114, baik melalui jaringan wi-fi maupun seluler. Nilai packet loss ukuran data 450 byte pada jaringan wifi sebesar $0.266667 \%$, sedangkan pada jaringan seluler nilai packet loss nya sebesar $0.133333 \%$. Nilai throughput yang dimiliki oleh ukuran data 450 byte sebesar $8992.347 \mathrm{bps}$ jika dikirim melalui jaringan wi-fi, sedangkan jika dikirim melalui jaringan seluler, nilai throughput nya sebesar 9004.373 bps. Ukuran data 450 byte yang tidak terlalu pendek dan tidak terlalu panjang sesuai dengan kebutuhan. Ukuran data 50, 150, 250, dan 350 memiliki panjang data kurang panjang. Agar lebih jelas, berikut grafik dan tabel hasil analisis:

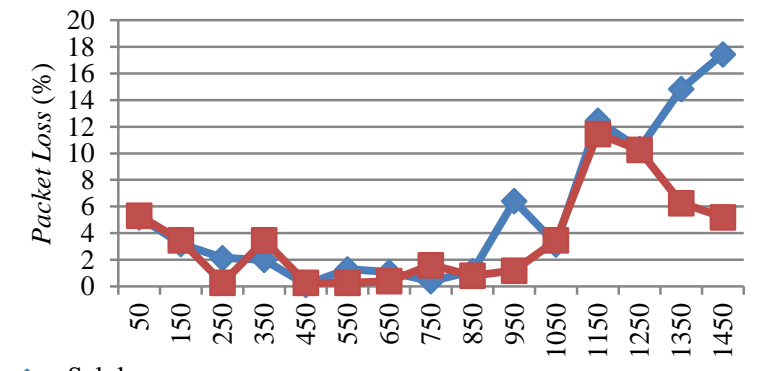

$$
\begin{aligned}
& \text { Seluler } \\
& -\mathrm{W} \text { Wifi }
\end{aligned}
$$

Ukuran Data (Byte)

Gambar 14 Perbandingan Packet Loss Wi-Fi dengan seluler

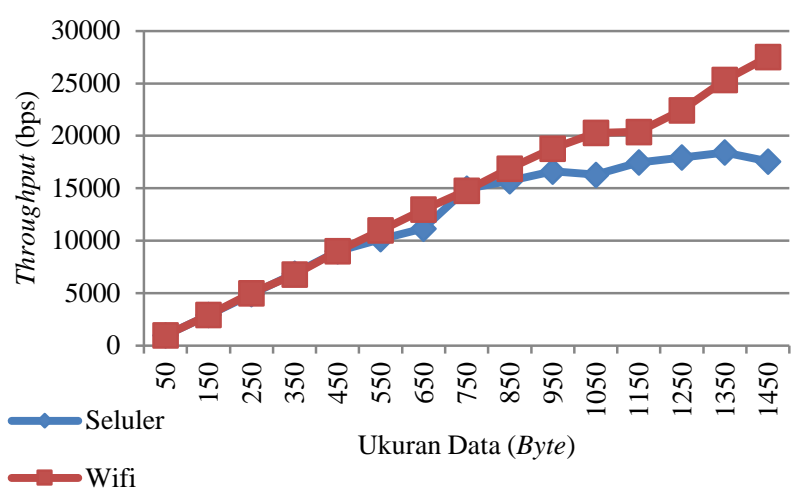

Gambar 15 Perbandingan Throughput Wi-Fi dengan seluler

Tabel 1

Kriteria Ukuran Data

\begin{tabular}{|l|l|l|l|l|l|l|l|l|l|l|l|}
\hline \multirow{2}{*}{ Wifi } & \multicolumn{10}{|c|}{ Ukuran Data (Byte) } \\
\cline { 2 - 13 } & 450 & 550 & 650 & 750 & 850 & 950 & 1050 & 1150 & 1250 & 1350 & 1450 \\
\hline PL & $\sqrt{ }$ & $\sqrt{ }$ & $\sqrt{ }$ & $\sqrt{ }$ & $\sqrt{ }$ & $\sqrt{ }$ & $\sqrt{ }$ & $\mathrm{x}$ & $\mathrm{x}$ & $\mathrm{x}$ & $\mathrm{x}$ \\
\hline Thr & $\sqrt{ }$ & $\sqrt{ }$ & $\sqrt{ }$ & $\sqrt{ }$ & $\sqrt{ }$ & $\sqrt{ }$ & $\sqrt{ }$ & $\sqrt{ }$ & $\sqrt{ }$ & $\sqrt{ }$ & $\sqrt{ }$ \\
\hline Panjang & $\sqrt{ }$ & $\mathrm{x}$ & $\mathrm{x}$ & $\mathrm{x}$ & $\mathrm{x}$ & $\mathrm{x}$ & $\mathrm{x}$ & $\mathrm{x}$ & $\mathrm{x}$ & $\mathrm{x}$ & $\mathrm{x}$ \\
\hline \multirow{2}{*}{ Seluler } & \multicolumn{10}{|c|}{ Ukuran Data (Byte) } \\
\cline { 2 - 13 } & 450 & 550 & 650 & 750 & 850 & 950 & 1050 & 1150 & 1250 & 1350 & 1450 \\
\hline PL & $\sqrt{ }$ & $\sqrt{ }$ & $\sqrt{ }$ & $\sqrt{ }$ & $\sqrt{ }$ & $\mathrm{x}$ & $\sqrt{ }$ & $\mathrm{x}$ & $\mathrm{x}$ & $\mathrm{x}$ & $\mathrm{x}$ \\
\hline Thr & $\sqrt{ }$ & $\sqrt{ }$ & $\sqrt{ }$ & $\sqrt{ }$ & $\sqrt{ }$ & $\sqrt{ }$ & $\sqrt{ }$ & $\sqrt{ }$ & $\sqrt{ }$ & $\sqrt{ }$ & $\sqrt{ }$ \\
\hline Panjang & $\sqrt{ }$ & $\mathrm{x}$ & $\mathrm{x}$ & $\mathrm{x}$ & $\mathrm{x}$ & $\mathrm{x}$ & $\mathrm{x}$ & $\mathrm{x}$ & $\mathrm{x}$ & $\mathrm{x}$ & $\mathrm{x}$ \\
\hline
\end{tabular}

Berikut isi data yang dapat diterapkan sesuai dengan rekomendasi:

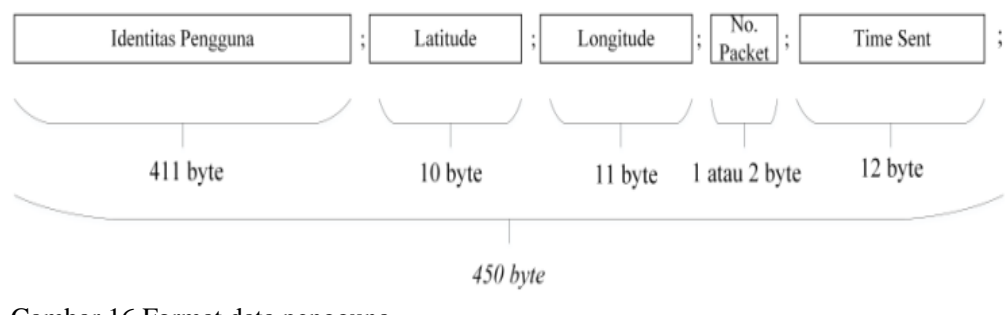

Gambar 16 Format data pengguna

Ukuran data 450 byte dapat berisi identitas pengguna sebesar 411 byte. Dalam prakteknya nanti identitas pengguna dapat dipecah lagi menjadi beberapa bagian, seperti nomor ID, nama pengguna, dan klasifikasi pentarifan yang terdiri dari kelompok usia, kepala tiket, dan biaya yang harus dibayar. Latitude sebesar 10 byte. Longitude sebesar 11 byte. Nomor paket sebesar 1 atau 2 byte, Time Sent sebesar 12 byte. Time sent terdiri dari jam, menit, detik, dan mili detik (hh:mm:sszz). Pemisah tiap bagian data berupa titik koma (;) memiliki ukuran data sebesar 1 byte.

Rekomendasi ukuran data ini dapat berlaku pada kondisi seperti pada pengujian ini.

\section{KESIMPULAN}

Dari tugas akhir ini dapat ditarik kesimpulan:

1. Pengujian sistem client-server mengenai penerimaan data oleh server, penyimpanan data data dalam database server, 
dan penyimpanan data balasan ke client telah sesuai rancangan. Sistem yang disimulasikan mampu memenuhi kebutuhan selama proses pengiriman dan penerimaan.

2. Pengujian packet loss terkecil pengiriman data melalui jaringan wi-fi terletak pada ukuran data 250, 450, dan 550 byte sebesar $0.26667 \%$ (perfect). Sedangkan pada jaringan seluler nilai packet loss terkecil terletak pada ukuran data 450 byte sebesar $0.13333 \%$ (perfect).

3. Nilai throughput berbanding lurus dengan ukuran data yang diterima.

4. Rekomendasi ukuran data yang dapat diterapkan pada sistem komunikasi terintegrasi angkutan massal cepat Surabaya, yaitu sebesar 450 byte. Rekomendasi ini berlaku pada kondisi seperti pengukuran ini.

\section{DAFTAR PUSTAKA}

[1] Farhana, Nurul. "Pengembangan Aplikasi Remote Spesifikasi Dekstop Berbasis Client Server," Universitas Islam Negeri Syarif Hidayatullah, Jakarta, 2011.

[2] Yuliantoro, Prasetyo. "Rancang Bangun Protokol E-Ticketing," Institut Teknologi Sepuluh Nopember, Surabaya, 2015.

[3] Faesal, Andris. "Pemrograman Client-server dengan Borland Delphi 7 dan My SQL," STMIK Bumigora, Mataram, 2012.

[4] Sastriyana, Nym Yuni. "Perancangan dan Analisis Interkoneksi Jaringan pada Electronic Toll Collection Berbasis Radio Frequency Identification (RFID)," Institut Teknologi Sepuluh Nopember, Surabaya, 2010. 